\title{
Gyrodactylus salinae n. sp. (Platyhelminthes: Monogenea) infecting the south European toothcarp Aphanius fasciatus (Valenciennes) (Teleostei, Cyprinodontidae) from a hypersaline environment in Italy
}

Giuseppe Paladini ${ }^{1 *}$, Tine Huyse ${ }^{2}$ and Andrew P Shinn ${ }^{1}$

\begin{abstract}
Background: Historically, non-native species of Gambusia (Poeciliidae) have been used to control larval stages of the Asian tiger mosquito, Stegomyia albopicta Reinert, Harbach et Kitching, 2004 throughout Italy. The potential utility of indigenous populations of Aphanius fasciatus (Valenciennes) (Teleostei: Cyprinodontidae) as an appropriate alternative biological control is currently being explored. A sub-sample of ten fish collected from Cervia Saline, Italy (salinity $65 \mathrm{ppt} ; 30^{\circ} \mathrm{C}$ ) to assess their reproductive capability in captivity, harboured a moderate infection of Gyrodactylus von Nordmann, 1832 (Platyhelminthes, Monogenea). A subsequent morphological and molecular study identified this as being a new species.
\end{abstract}

Results: Gyrodactylus salinae n. sp. is described from the skin, fins and gills of A. fasciatus. Light and scanning electron microscopical (SEM) examination of the opisthaptoral armature and their comparison with all other recorded species suggested morphological similarities to Gyrodactylus rugiensoides Huyse et Volckaert, 2002 from Pomatoschistus minutus (Pallas). Features of the ventral bar, however, permit its discrimination from G. rugiensoides. Sequencing of the nuclear ribosomal DNA internal transcribed spacers 1 and 2 and the 5.85 rRNA gene and a comparison with all species listed in GenBank confirmed they are unique and represent a new species (most similar to Gyrodactylus anguillae Ergens, 1960, 8.3\% pair-wise distance based on 5.8S+ITS2). This represents the first species of Gyrodactylus to be described from Aphanius and, to date, has the longest ITS1 (774 bp) sequenced from any Gyrodactylus. Additional sampling of Cervia Saline throughout the year, found G. salinae n. sp. to persist in conditions ranging from $35 \mathrm{ppt}$ and $5^{\circ} \mathrm{C}$ in December to $65 \mathrm{ppt}$ and $30^{\circ} \mathrm{C}$ in July, while in captivity a low level of infection was present, even in freshwater conditions (0 ppt).

Conclusions: The ability of G. salinae n. sp. to tolerate a wide range of salinities and temperatures shows its potential to readily adapt to several environmental conditions. These findings, together with the fact that $A$. fasciatus is a protected species and is considered as a biological control organism, necessitate further studies on the ecology and virulence of G. salinae n. sp.

\footnotetext{
* Correspondence: paladini2000@yahoo.it

'Institute of Aquaculture, University of Stirling, Stirling, FK9 4LA, Scotland, UK

Full list of author information is available at the end of the article
} 


\section{Background}

Toothcarp is a colloquial term used to describe members of the order Cyprinodontiformes, which comprises ten fish families, namely Anablepidae, Aplocheilidae, Cyprinodontidae, Fundulidae, Goodeidae, Nothobranchiidae, Poeciliidae, Profundulidae, Rivulidae and Valenciidae [1]. Within the family Cyprinodontidae, the south European toothcarp Aphanius fasciatus (Valenciennes) is one of the more commonly occurring neritic species within the Mediterranean and is characteristically known to be an eurythermic and euryhaline fish species, for its ability to tolerate a wide range of temperatures $\left(5-39^{\circ} \mathrm{C}\right)$ and salinities (0-180 ppt), respectively [2]. Aphanius fasciatus has a widespread distribution along the Italian coastline, principally in brackish waters [3], although increasing anthropogenic activity has caused a general decline in numbers. For this reason, $A$. fasciatus is considered to be a species that is "dying out" and as such, is listed under Appendix III "Protected Fauna Species" after the Bern Convention on the conservation of European wildlife and natural habitats, and under Annex II of the Council Directive $92 / 43 / \mathrm{EEC}$ on the conservation of natural habitats and of wild fauna and flora in the European Community [4]. It has recently been used as a biological control against the larvae of the Asian tiger mosquito Stegomyia albopicta (= Aedes albopictus) Reinert, Harbach et Kitching, 2004 which are vectors for a range of human infectious diseases, including Chikungunya fever, dengue fever, West Nile fever and yellow fever [5-7].

During a recent research study investigating the artificial reproduction of $A$. fasciatus in captivity as part of a large scale restocking and mosquito control initiative in Italy $[8,9]$, several specimens collected, under licence, on a number of occasions were found to harbour an infection of Gyrodactylus von Nordmann, 1832, principally on the skin and fins and, to a lesser degree, on the gills. Infected tissues were removed from the moribund fish and subsequently sent to the Institute of Aquaculture, University of Stirling (Scotland, UK) for identification. Given the importance of $A$. fasciatus as a protected species and its utility as an alternative indigeneous biological control agent to the introduced Gambusia spp. (Poeciliidae), more information on its Gyrodactylus fauna was needed.

\section{Methods}

\section{Specimens collection and preparation}

A total of ten adult $A$. fasciatus (total length 4-7 cm; weight $\sim 3$ g) was collected during July 2008 from isolated pools in Cervia Saline, located in the Emilia Romagna region in northern Italy, and fixed in $70 \%$ ethanol. All ten specimens collected from the drying, landlocked pools were moribund individuals, a consequence of reduced water availability and increased algal growth. The skin, fins and gills of each fish were subsequently screened for metazoan parasites using an Olympus SZ40 stereomicroscope at $\times 4$ magnification. Specimens of Gyrodactylus were removed using mounted triangular surgical needles. All ten fish were infected but given the condition of the fish on collection, the intensity of infection can only be estimated at between 10-30 parasites per fish.

The alcohol-fixed parasites were subsequently rinsed in distilled water and representatives prepared as whole mounts using ammonium picrate glycerine following the procedure detailed by Malmberg [10]. Additional specimens had their opisthaptors removed using a scalpel, which were then individually subjected to proteolytic digestion on glass slides, as described in Paladini et al. [11]. The largely tissue-free opisthaptoral hook preparations were then mounted in ammonium picrate glycerine using an $18 \times 18 \mathrm{~mm}$ coverslip, the edges of which were sealed with a commercial brand of nail varnish. The corresponding body of each specimen of Gyrodactylus was fixed in $90 \%$ ethanol for subsequent molecular characterisation.

For scanning electron microscopy (SEM), single specimens of Gyrodactylus were subjected to full proteolytic digestion on $11 \mathrm{~mm}$ round glass coverslips to obtain tissue-free attachment hooks. Each digestion took approximately $60 \mathrm{~min}$, with $3 \mu \mathrm{l}$ of digestion solution being added every $10 \mathrm{~min}$, punctuated by the addition of $5 \mu \mathrm{l}$ distilled water for five times to remove digested tissue residues and debris. For each step, the digested hook preparations were placed in a Petri dish to protect them from extraneous dust and placed in an incubator at $55^{\circ} \mathrm{C}$ to help digestion, followed by a final incubation at $40^{\circ} \mathrm{C}$ overnight to dry. The position of hooks on each coverslip was subsequently marked using tiny, adhesive, triangular labels positioned using forceps under an Olympus BX51 compound microscope at $\times 10$ magnification. The coverslips were then attached onto aluminium stubs with bi-adhesive round labels, sputter-coated with gold using an Edwards S150B sputter coater and then examined using a JEOL JSM5200 SEM operating at an accelerating voltage of $10 \mathrm{kv}$.

\section{Morphological analysis}

For the morphological study, images of the opisthaptoral hard parts and the male copulatory organ (MCO) were captured at magnifications of $\times 40$ and $\times 100$ oil immersion using MRGrab 1.0.0.4 (Carl Zeiss Vision GmbH, 2001) software and a Zeiss AxioCam MRc digital camera mounted on an Olympus BX51 compound microscope, using a $\times 0.75$ interfacing lens. Drawings of the taxonomic features were made from the captured 
images. Each Gyrodactylus specimen was subjected to morphometric analysis taking a total of 27 point-topoint measurements on the opisthaptoral hooks using a JVC KY-F30B 3CCD video camera mounted on an Olympus $\mathrm{BH} 2$ microscope using a $\times 2.5$ interfacing lens at $\times 100$ oil immersion and the KS300 (ver.3.0) (Carl Zeiss Vision $\mathrm{GmbH}$, 1997) image analysis software, combined with the specific macro for gyrodactylids, Point-R (Bron \& Shinn, University of Stirling). The point-to-point hook measurements for the specimens are given in micrometres as the mean \pm 1 standard deviation followed by the range in parentheses, and follow those described in Shinn et al. [12], plus three additional measurements of the dorsal bar (total length, width and attachment point length).

The gyrodactylid material prepared from $A$. fasciatus was compared to type material of Gyrodactylus rugiensoides Huyse et Volckaert, 2002 (paratypes acc. nos. BMNH 2002.2.14.2-3), a species with morphologically similar marginal hooks, held in the Parasitic Worms collection at The Natural History Museum, London, UK. In addition, type material of the six Gyrodactylus species known to parasitise cyprinodontid hosts, held in the U.S. National Parasite Collection, Beltsville, Maryland, USA, was examined, the marginal hooks re-drawn and compared to the new specimens collected from A. fasciatus. These are Gyrodactylus cyprinodontis Mizelle et Kritsky, 1967 (holotype and paratype acc. no. USNPC 62951), Gyrodactylus hargisi Williams et Rogers, 1971 (paratypes acc. no. USNPC 71760), Gyrodactylus mobilensis Williams et Rogers, 1971 (paratypes acc. no. USNPC 71762), Gyrodactylus nevadensis Mizelle et Kritsky, 1967 (holotype and paratype acc. no. USNPC 62954), Gyrodactylus saratogensis Mizelle et Kritsky, 1967 (paratype acc. no. USNPC 62956) and Gyrodactylus tularosae Kritsky et Stockwell, 2005 (paratype acc. no. USNPC 94780).

\section{Molecular analysis}

The bodies of 2 specimens were individually transferred to a $0.2 \mathrm{ml}$ microcentrifuge tube containing $5 \mu \mathrm{l}$ of milli-Q water and digested by the addition of $5 \mu \mathrm{l}$ of lysis solution consisting of $1 \times \mathrm{PCR}$ buffer (Eurogentec, Seraing, Belgium), 0.45\% (v/v) Tween 20, 0.45\% (v/v) NP 40 and $60 \mu \mathrm{g} / \mathrm{ml}$ of proteinase K (Sigma, Poole, UK). The samples were incubated at $65^{\circ} \mathrm{C}$ for $25 \mathrm{~min}$, followed by $10 \mathrm{~min}$ at $95^{\circ} \mathrm{C}$ to inactivate the proteinase. The primer pairs ITS1A (5'-GTAACAAGGTTT CCGTAGGTG-3') and ITS2 (5'-TCCTCCGCTTAGTGATA- 3') [13] were used to amplify a fragment spanning the 3' end of the $18 \mathrm{~S}$ rRNA gene, the internal transcribed spacer 1 (ITS1), the 5.8S rRNA gene, ITS2, and the 5' end of the $28 \mathrm{~S}$ rRNA gene. The amplification reactions $(20 \mu \mathrm{l})$ consisted of $1 \times$ PCR buffer, $1.5 \mathrm{mM}$
$\mathrm{MgCl}_{2}$ (Eurogentec, Seraing, Belgium), $200 \mu \mathrm{M}$ of each dNTP (Amersham Pharmacia Biotech, Uppsala, Sweden), $1 \mu \mathrm{M}$ of each primer (Eurogentec, Seraing, Belgium), $2 \mu$ lysate, 1 unit Taq polymerase (Eurogentec, Seraing, Belgium) and milli-Q water. The mixtures were heated for $4 \mathrm{~min}$ at $96^{\circ} \mathrm{C}$ and subjected to 35 cycles of $1 \mathrm{~min}$ at $95^{\circ} \mathrm{C}, 1 \mathrm{~min}$ at $50^{\circ} \mathrm{C}$ and $2 \mathrm{~min}$ at $72^{\circ}$ $\mathrm{C}$, followed by a final extension at $72^{\circ} \mathrm{C}$ for $7 \mathrm{~min}$. The PCR products were visualised using ethidium bromide on a $1.2 \%$ agarose gel. The products were then purified by means of GFX columns according to the manufacturer's instructions (Amersham Pharmacia Biotech, Uppsala, Sweden). Both DNA strands were sequenced using a Big Dye Chemistry Cycle Sequencing Kit (version 1.1) in a 3130 DNA Analyzer (Applied Biosystems, Belgium). The PCR primers and 2 internal primers, ITS1R (5'-ATTT GCGTTCGAGAGACCG-3') and ITS2F (5'-TGGTGGATCA CTCGGCTCA-3') [14], were used for sequencing.

The obtained sequences were subjected to a BLAST search (available at http://www.ncbi.nih.gov/BLAST/) to identify similar sequences among other species of Gyrodactylus in GenBank [15]. The sequences with the highest similarity to our sequences were downloaded and the $5.8 \mathrm{~S}$ and ITS2 fragments were aligned in Clustal W implemented in MEGA 4 [16]. Pair-wise genetic distances were computed in MEGA 4 according to the evolutionary model that was selected by jModelTest 0.1 .1 [17]. The sequences were also scanned for repeat elements using the program Tandem Repeats Finder [18].

\section{Results \\ Gyrodactylus salinae n. sp \\ Type host}

Aphanius fasciatus (Valenciennes), Cyprinodontidae ("South European toothcarp", "nono").

\section{Site of infection}

Skin, fins and occasionally gills.

Type locality

Cervia Saline, Emilia Romagna region, Italy $\left(44^{\circ} 14^{\prime} \mathrm{N}, 12^{\circ}\right.$ 20'E).

\section{Environmental conditions under which specimens were collected}

Salinity and temperature in July 2008, 65 ppt and $30^{\circ} \mathrm{C}$, respectively.

\section{Type material}

Fifteen specimens were studied for light microscopy. Holotype (acc. no. BMNH 2011.5.19.1) and four paratypes (acc. nos. BMNH 2011.5.19.2-5) are deposited in the parasitic worm collection at The Natural History Museum, London. Additionally, three paratypes (acc. no. M-521) are deposited in the gyrodactylid collection held at the Institute of Parasitology, Academy of Sciences of the Czech Republic, České Budějovice; four paratypes 
(acc. nos. AHC 35118-35121) are deposited in the Australian Helminthological Collection (AHC) of The South Australian Museum (SAMA), North Terrace, Adelaide; and three paratypes (acc. nos. USNPC 104748-104750) are deposited in the United States National Parasite Collection, Beltsville, Maryland, USA.

\section{Molecular sequence data}

The sequence fragment of approximately $1379 \mathrm{bp}$ encoding partial 18S (32 bp), ITS1 (774 bp), 5.8S (158 bp), ITS2 (402 bp) and partial 28S (13 bp) is deposited in GenBank under accession no. JF950559.

\section{General}

A species profile including host and taxonomic details is provided on the on-line databases http://www.gyrodb. net[19] and http://www.monodb.org[20].

\section{Etymology}

Named after the Italian generic name for a hypersaline water body i.e. "salina" (= saline in English) and the broad salinity tolerance exhibited by this species of Gyrodactylus.

\section{Morphological description (Figure 1, 2, 3; Table 1)}

Based on the measurements of fifteen specimens. Body elongate, 447 (375-575) long, 116 (88-163) wide. Prohaptor with a single pair of cephalic lobes each bearing a gland and a spike sensillum. Pharynx small, anterior pharyngeal bulb 18.8 (15.0-24.5) long, 22.1 (19.5-27.2) wide; posterior pharyngeal bulb 8.1 (6.6-8.8) long, 24.6 (21.8-29.0) wide. Intestinal crura extending beyond the anterior edge of the testes. Presence or absence of excretory bladders not discernible on whole mounts. Opisthaptor ovate, 75 (60-88) long $\times 80(70-88)$ wide. Male copulatory organ (MCO) spherical, 14.4 (11.9-18.5) long $\times 12.7$ (10.1-17.6) wide, armed with one principal spine and 9 small spines in a single row. MCO position variable, usually on the left, posterior to the posterior pharyngeal bulb. Total length of hamuli 51.7 (48.7-54.6); hamulus shaft length 31.9 (28.2-37.3); hamulus point 24.8 (23.9-25.9) long, arising at an angle of $41.4^{\circ}\left(39.2-43.5^{\circ}\right)$ (internal measurement) to the shaft of the hamulus; hamulus root 16.8 (14.7-18.3) long.

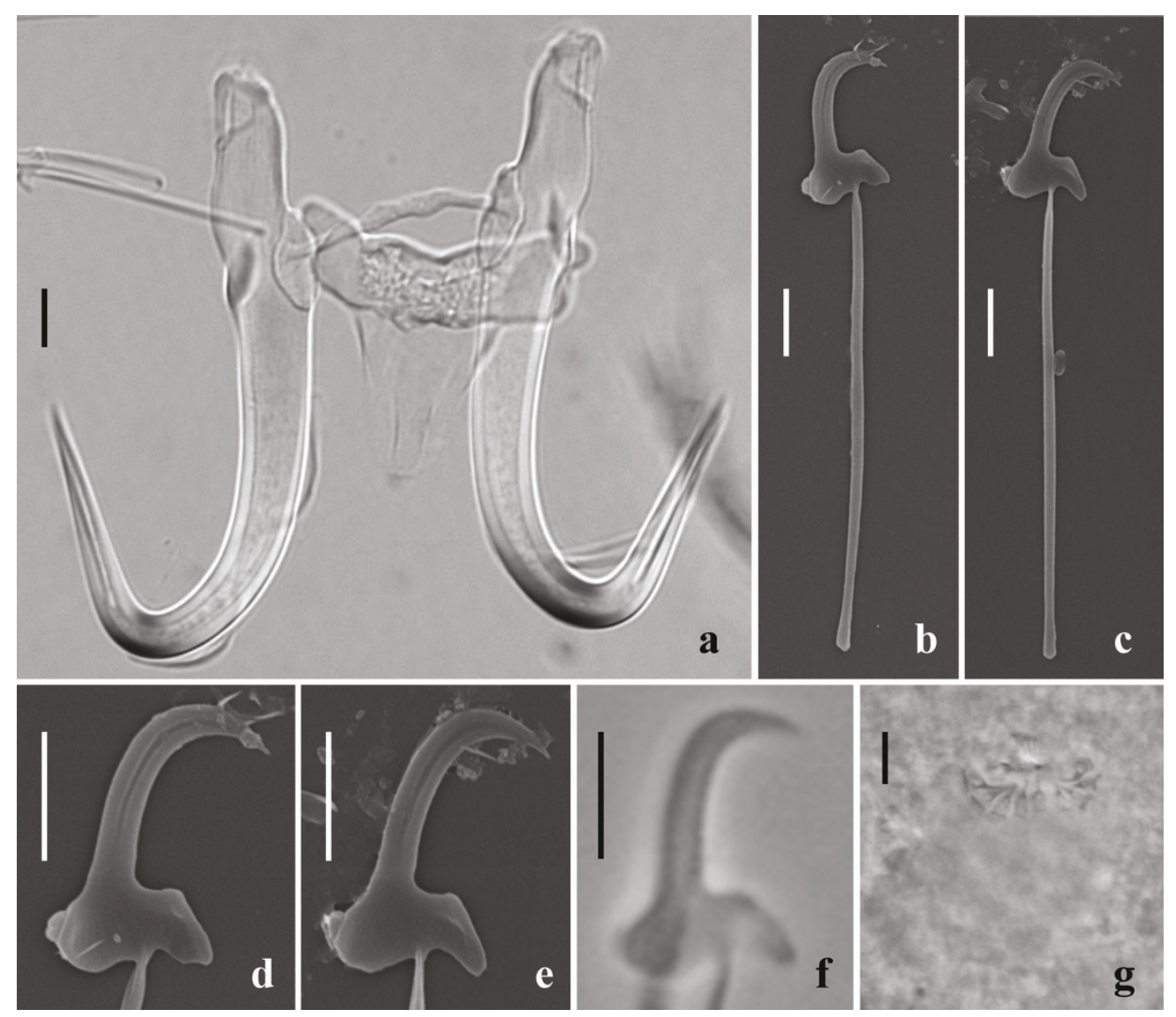

Figure 1 Gyrodactylus salinae n. sp. from the south European toothcarp Aphanius fasciatus (Valenciennes) from Cervia Saline, Italy. a light micrograph of the opisthaptoral central hook complex showing the hamuli, the dorsal bar and the ventral bar (ventral view); b, c scanning electron micrographs (SEM) of the marginal hooks; $\mathbf{d}$, e - SEM of the marginal hook sickles; $\mathbf{f}$ - light micrograph of a marginal hook sickle; $\mathbf{g}$ - light micrograph of the male copulatory organ (MCO) bearing one principal spine and nine small spines in a single row. Scale bars: a $=5 \mu \mathrm{m} ; \mathbf{b}-\mathbf{g}=3 \mu \mathrm{m}$ 

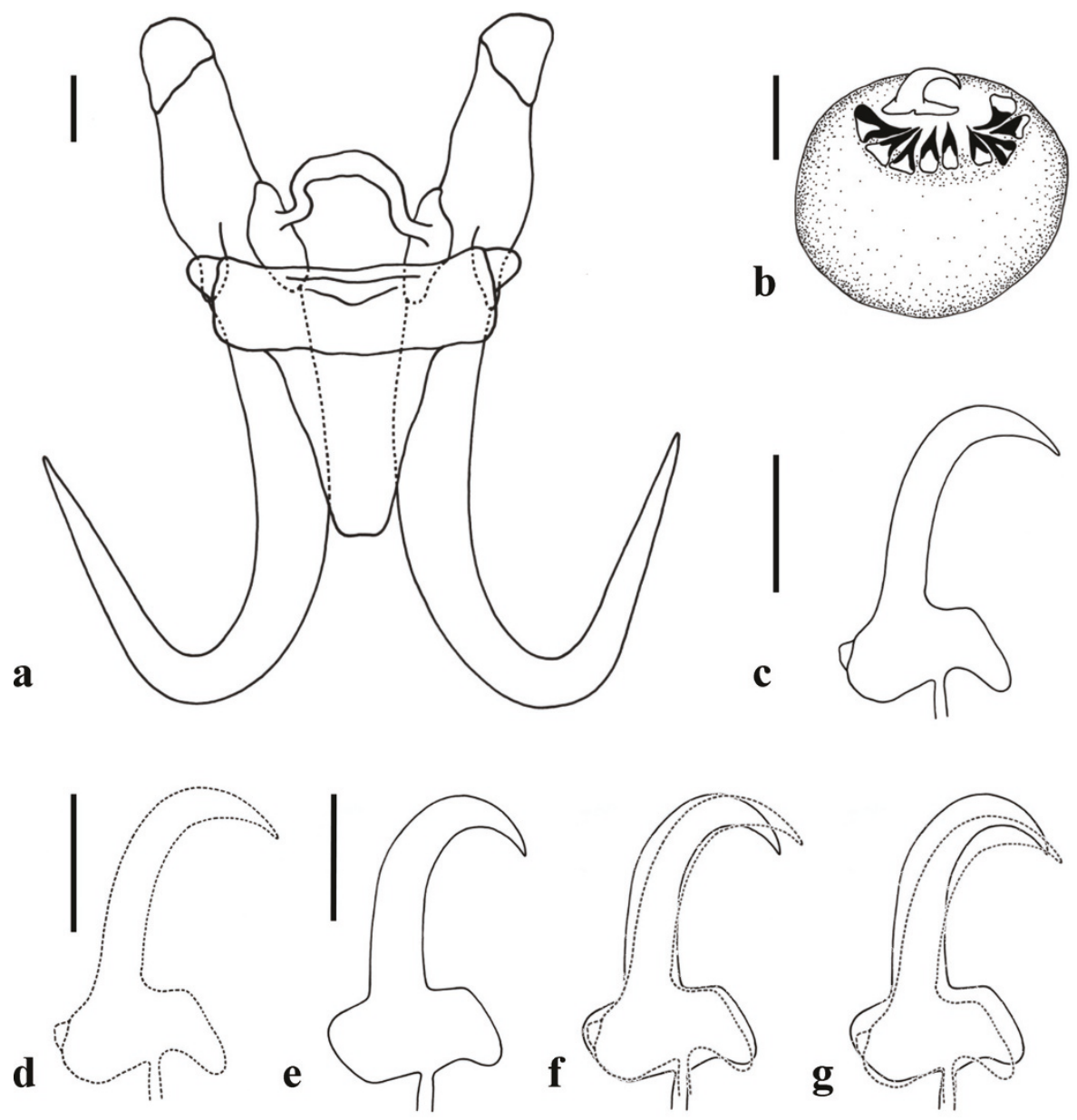

Figure 2 Drawings of the opisthaptoral hard parts and male copulatory organ (MCO) of Gyrodactylus salinae n. sp. from the south European toothcarp Aphanius fasciatus (Valenciennes) from Cervia Saline, Italy. a - opisthaptoral central hook complex; b - MCO; c, d - marginal hook sickles; e - marginal hook sickle of Gyrodactylus rugiensoides Huyse et Volckaert, 2002 from Pomatoschistus minutus (Pallas) collected from Texel, The Netherlands (re-drawn from the paratype 2002.2.14.2); $\mathbf{f}$ - a size invariant overlay of the marginal hook sickles of $G$. salinae n. sp. (broken line) with G. rugiensoides (solid line); $\mathbf{g}$ - a size variant overlay of the marginal hook sickles of G. salinae n. sp. (broken line) with $G$. rugiensoides (solid line). Scale bars: $\mathbf{a}, \mathbf{b}=5 \mu \mathrm{m} ; \mathbf{c}-\mathbf{e}=3 \mu \mathrm{m}$.

Dorsal bar attachment points on hamuli 9.4 (8.8-9.9) long. Dorsal bar simple, 20.9 (18.1-22.9) long, 1.9 (1.6-2.2) wide irregular and slightly thickened at its midpoint. Ventral bar triangular in approximate dimensions, 22.5 (19.2-25.5) long, 25.0 (23.5-26.7) wide; ventral bar processes prominent, arise tangentially to the extremities of the median portion of the ventral bar proper, 2.9 (2.1-3.5) long; ventral bar membrane long, approximately triangular with a smoothly rounded terminal edge, 13.2 (10.7-15.2) long. Total length of marginal hooks 26.8 (25.9-27.6); marginal hook shaft 20.8 (20.221.5) long; marginal hook sickle proper 6.3 (6.1-6.6) long. Sickle shaft approximately perpendicular to the base, very slightly angled forward, proportionately slender, turns at a near right angle into a narrow tip which terminates at a point beyond the perpendicular limit of the toe. Sickle distal width 3.6 (3.3-4.0), proximal width 4.0 (3.6-4.4). Aperture of marginal sickle, open, 5.6 (5.4-6.0) long, inner curve of the sickle approximately rectangular. Sickle base has a flat bridge; triangular toe 1.8 (1.6-2.0) long; prominent rounded heel, tangential to the sickle base, downwardly directed. The sickle heel appears square in dimensions in specimens prepared for light microscopy but SEM images reveal a rounded heel with an additional prominent button for muscle attachment (Figure 1b-e).

\section{Molecular characterisation}

The total fragment (1379 bp) consists of the 3' end of the $18 \mathrm{~S}$ subunit ( $32 \mathrm{bp})$, the ITS1 ( $774 \mathrm{bp})$, the $5.8 \mathrm{~S}$ gene (158 bp), the ITS2 (402 bp) and the 5' end of the $28 \mathrm{~S}$ subunit (13 bp). Both specimens had identical 


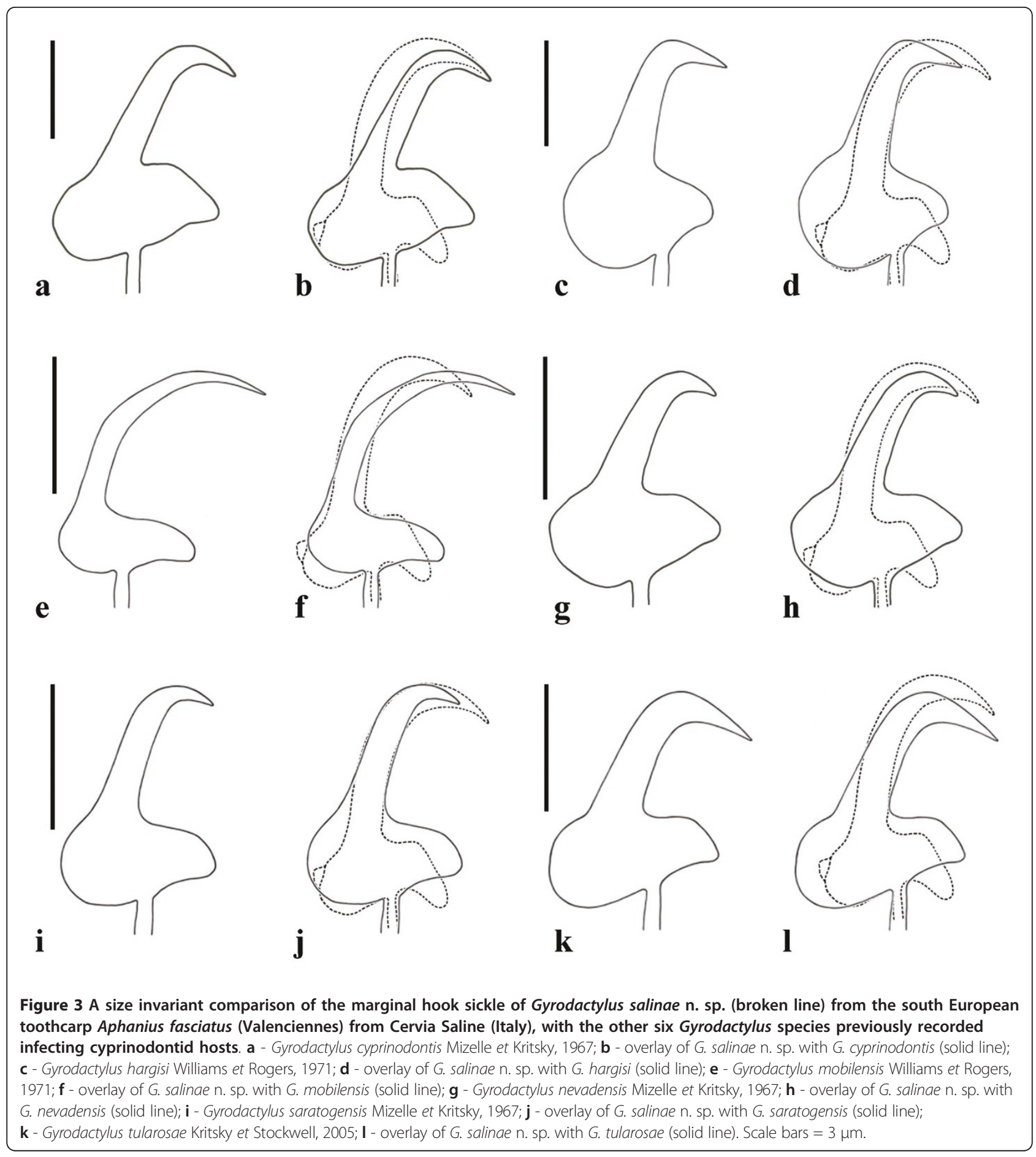

sequences. Gyrodactylus salinae n. sp. appeared most closely related to Gyrodactylus species belonging to the G. (Paranephrotus) and G. (Neonephrotus) sub-genera (sub-genera according to Malmberg [10]) based on the pair-wise distances (Tamura-Nei gamma corrected distances [21] using the 5.8S-ITS2 fragment, Table 2); it is most closely related to Gyrodactylus anguillae Ergens,
1960 (8.3\%; acc. no. AB063294) and Gyrodactylus micropsi Gläser, 1974 (8.6\%; acc. no. AF328868). The pair-wise distance with G. rugiensoides, the species whose attachment hooks are morphologically similar to those of G. salinae n. sp., amounted to $14 \%$. Of all available ITS rDNA sequences of Gyrodactylus (146 on GenBank), G. salinae n. sp. has the longest ITS1 
Table 1 Morphological measurements (mean \pm 1 standard deviation followed by the range in parentheses) of Gyrodactylus salinae n. sp. from Aphanius fasciatus (Valenciennes) collected from Cervia Saline, Italy, compared with those of Gyrodactylus rugiensoides Huyse et Volckaert, 2002 from Pomatoschistus minutus (Pallas) collected from Texel, The Netherlands (paratypes acc. nos. BMNH 2002.2.14.2-3)

\begin{tabular}{|c|c|c|}
\hline Variable & $\begin{array}{l}\text { Gyrodactylus salinae } n . \text { sp. } \\
\qquad(\mathrm{n}=15)\end{array}$ & $\begin{array}{l}\text { Gyrodactylus rugiensoides Huyse et Volckaert, } 2002 \\
\qquad(\mathrm{n}=2)\end{array}$ \\
\hline Total body length & $447 \pm 63.3(375-575)$ & $787.5(700-875)$ \\
\hline Total body width & $116 \pm 26.7(88-163)$ & $159(155-162.5)$ \\
\hline Opisthaptor length $\times$ width & $75 \pm 8.9(60-88) \times 80 \pm 5.7(70-88)$ & $112.5(110-115) \times 147.5(145-150)$ \\
\hline Anterior pharynx bulb length $\times$ width & $18.8 \pm 3.1(15.0-24.5) \times 22.1 \pm 2.4(19.5-27.2)$ & $32.9(30.1-35.7) \times 48.3(46.8-49.7)$ \\
\hline Posterior pharynx bulb length $\times$ width & $8.1 \pm 0.7(6.6-8.8) \times 24.6 \pm 2.4(21.8-29.0)$ & $34.1(27.7-40.5) \times 78.4(76.5-80.4)$ \\
\hline MCO length $\times$ width & $14.4 \pm 2.1(11.9-18.5) \times 12.7 \pm 2.7(10.1-17.6)^{1}$ & $14.8(13.6-15.9) \times 15.1(14.0-16.1)$ \\
\hline \multicolumn{3}{|l|}{ Hamulus (H) } \\
\hline $\mathrm{H}$ aperture & $17.9 \pm 0.8(17.0-19.6)$ & $18.0(17.5-18.5)$ \\
\hline H proximal shaft width & $7.0 \pm 0.6(6.3-8.1)$ & $8.1(7.6-8.6)$ \\
\hline $\mathrm{H}$ point length & $24.8 \pm 0.5(23.9-25.9)$ & $29.9(29.3-30.5)$ \\
\hline $\mathrm{H}$ distal shaft width & $4.1 \pm 0.4(3.2-4.6)$ & $5.4(5.3-5.4)$ \\
\hline $\mathrm{H}$ shaft length & $31.9 \pm 2.9(28.2-37.3)$ & $33.8(33.5-34.2)$ \\
\hline $\mathrm{H}$ inner curve length & $3.8 \pm 0.6(2.3-4.6)$ & $3.9(3.5-4.3)$ \\
\hline $\mathrm{H}$ aperture angle $\left(^{\circ}\right)$ & $36.6 \pm 1.2(33.8-37.9)$ & $32.5(30.7-34.4)$ \\
\hline H point curve angle $\left(^{\circ}\right)$ & $12.2 \pm 2.3(7.4-15.4)$ & $10.1(9.4-10.7)$ \\
\hline Inner $\mathrm{H}$ aperture angle $\left(^{\circ}\right)$ & $41.4 \pm 1.3(39.2-43.5)$ & $38.5(36.4-40.7)$ \\
\hline $\mathrm{H}$ root length & $16.8 \pm 0.9(14.7-18.3)$ & $19.4(19.2-19.7)$ \\
\hline $\mathrm{H}$ total length & $51.7 \pm 1.6(48.7-54.6)$ & $58.1(57.9-58.2)$ \\
\hline \multicolumn{3}{|l|}{ Dorsal bar (DB) } \\
\hline DB total length & $20.9 \pm 1.7(18.1-22.9)$ & $25.6(23.8-27.4)$ \\
\hline DB width & $1.9 \pm 0.2(1.6-2.2)$ & $1.8(1.7-1.9)$ \\
\hline DB attachment point length & $9.4 \pm 0.4(8.8-9.9)$ & $8.7(8.6-8.7)$ \\
\hline \multicolumn{3}{|l|}{ Ventral bar (VB) } \\
\hline VB total width & $25.0 \pm 1.1(23.5-26.7)$ & $26.2(25.3-27.1)$ \\
\hline VB total length & $22.5 \pm 1.6(19.2-25.5)$ & $20.4(20.4-20.5)$ \\
\hline VB process-to-mid length & $3.0 \pm 0.5(2.1-4.0)$ & $2.0(1.8-2.3)$ \\
\hline VB median length & $6.2 \pm 0.4(5.6-6.8)$ & $6.2(5.9-6.6)$ \\
\hline VB process length & $2.9 \pm 0.4(2.1-3.5)$ & $1.2(1.1-1.3)$ \\
\hline VB membrane length & $13.2 \pm 1.1(10.7-15.2)$ & $11.9(11.8-11.9)$ \\
\hline \multicolumn{3}{|l|}{ Marginal hook (MH) } \\
\hline MH total length & $26.8 \pm 0.6(25.9-27.6)$ & $30.7(30.7-30.8)$ \\
\hline MH shaft length & $20.8 \pm 0.3(20.2-21.5)$ & $24.3(24.1-24.5)$ \\
\hline MH sickle length & $6.3 \pm 0.2(6.1-6.6)$ & $6.6(6.3-6.9)$ \\
\hline MH sickle proximal width & $4.0 \pm 0.2(3.6-4.4)$ & $4.3(4.2-4.3)$ \\
\hline $\mathrm{MH}$ toe length & $1.8 \pm 0.1(1.6-2.0)$ & $1.7(1.6-1.7)$ \\
\hline MH sickle distal width & $3.6 \pm 0.2(3.3-4.0)$ & $3.7(3.5-3.9)$ \\
\hline MH aperture & $5.6 \pm 0.2(5.4-6.0)$ & $5.7(5.6-5.7)$ \\
\hline MH instep/arch height & $0.6 \pm 0.1(0.5-0.7)$ & $0.5(0.5-0.6)$ \\
\hline
\end{tabular}

Measurements are provided in micrometres and follow those detailed in Shinn et al. [12], plus three additional measurements of the dorsal bar. Due to the limited number of $G$. rugiensoides specimens available for study, only the mean and range is presented.

${ }^{1}$ Based on the measurement of 5 specimens.

fragment (774 bp), followed by Gyrodactylus teuchis Lautraite, Blanc, Thiery, Daniel et Vigneulle, 1999 (720 bp; acc. no. AJ249350). The ITS1 has a GC content of $42.1 \%$ and an imperfect repeat of an 8 bp motif (GAGAGAGT), starting at position 101 (copynumber
4.4). The ITS1 of G. anguillae and G. micropsi did not have any repeat element. The $5.8 \mathrm{~S}$ rRNA gene is 158 bp long, which is 1 bp longer than all other Gyrodactylus species sequenced so far; the ITS2 (402 bp) has a median size. 
Table 2 Pair-wise genetic distances based on the $5.8 \mathrm{~S}$ and ITS2 rDNA fragment of Gyrodactylus salinae n. sp. and the Gyrodactylus species showing highest similarity in the BLAST search on GenBank (Tamura-Nei + gamma model)

\begin{tabular}{lccccccc}
\hline Gyrodactylus species & $\mathbf{1}$ & $\mathbf{2}$ & $\mathbf{3}$ & $\mathbf{4}$ & $\mathbf{5}$ & $\mathbf{6}$ & $\mathbf{7}$ \\
\hline 1. G. salinae n. sp. & & & & & & & \\
2. G. anguillae & 0.083 & & & & & & \\
3. G. rugiensis & 0.135 & 0.139 & & & & & \\
4. G. micropsi & 0.086 & 0.088 & 0.113 & & & & \\
5. G. cf. micropsi & 0.097 & 0.076 & 0.121 & 0.048 & & & \\
6. G. rugiensoides & 0.140 & 0.151 & 0.023 & 0.124 & 0.132 & & \\
7. G. eyipayipi & 0.179 & 0.189 & 0.225 & 0.193 & 0.188 & 0.232 & \\
8. G. longidactylus & 0.112 & 0.098 & 0.128 & 0.075 & 0.091 & 0.137 & 0.191 \\
\hline
\end{tabular}

\section{Comments}

Morphologically, the opisthaptoral hooks, notably the marginal hook sickles, of G. salinae n. sp. are similar to those of G. rugiensoides described from the sand goby Pomatoschistus minutus (Pallas) collected from Texel, The Netherlands [22] (Figure 2d-g). Given the potential overlapping distribution of these two fish hosts within the Mediterranean Sea [1], it is important to detail the subtle features in hook morphology that permit their discrimination from one another. Two paratypes of G. rugiensoides were examined for morphological comparison with $G$. salinae n. sp. The paratypes were re-measured and the marginal hook sickle re-drawn and overlaid with G. salinae n. sp. for a direct comparison (Table 1; Figure 2e-g). There was a good agreement between the measurements obtained in the current study and those presented in Huyse \& Volckaert [22]. The present study, however, provides an additional set of measurements taken from the type material of G. rugiensoides for direct comparison with the opisthaptoral features of G. salinae n. sp. Although the hamuli roots in both species narrow after their union with the shaft, giving the anterior edge of the dorsal bar attachment point a small but distinct edge, this appears to be more prominent in G. rugiensoides than on the hamuli of G. salinae n. sp. The ventral bar attachment points also differ; those of G. rugiensoides appear flat and rectangular, while those of G. salinae n. sp. are indented. The prominent ventral bar processes and the longer, slender ventral bar membrane of G. salinae n. sp. contributes to the discrimination of the two species. The similar morphology of the marginal hook sickles of both species though, requires careful examination. The union of the marginal hook shaft with the sickle divides the width of the sickle base into 3:2 (heel:toe) in both species, however, the sickle base is deeper in G. rugiensoides than in G. salinae n. sp. with a more angular, rectangular heel and a steeper faced, more robust toe
(Figure 2f-g). The sickle shaft and sickle tip of G. rugiensoides is broader, proportionately so, than that of G. salinae $\mathrm{n}$. sp. giving the latter the appearance of having a more open deeper sickle aperture. A comparison of soft body features suggests that the posterior pharynx bulb of G. rugiensoides (78.4 $\mu \mathrm{m}$ in diameter) is considerably larger than that of G. salinae n. sp. which measures in $24.6 \mu \mathrm{m}$ in diameter. Although Huyse \& Volckaert [22] described the MCO of G. rugiensoides as armed with one principal spine and five small spines, a closer examination of the paratypes shows that G. rugiensoides possesses nine small spines, as that of G. salinae n. sp. The MCOs of the two species are similar in length (G. salinae n. sp. $14.4 \mu \mathrm{m} v s$ G. rugiensoides $14.8 \mu \mathrm{m}$ ) but that of G. rugiensoides is slightly wider (12.7 vs 15.1).

A molecular comparison of G. rugiensoides and G. salinae n. sp. showed that they were quite distinct. The pair-wise distance amounted to $14 \%$ (based on the $5.8 \mathrm{~S}+$ ITS2 fragment). The ITS1 sequences were more difficult to align, due to length differences (up to 132 $\mathrm{bp}$ ). Both species belong to the so-called marine rugiensis-group that also includes G. anguillae.

Additional sampling A. fasciatus from the Cervia Saline at several time points throughout the year, found that G. salinae n. sp. was present on their hosts in waters ranging from $35 \mathrm{ppt}$ and $5^{\circ} \mathrm{C}$ during December to $65 \mathrm{ppt}$ and $30^{\circ} \mathrm{C}$ during July in the wild, while under captive conditions, fish even maintained a low level of infection in freshwater (0 ppt) (pers. obs.).

\section{Discussion}

Gyrodactylus salinae n. sp. is the first species to be formally described from Aphanius fasciatus and, also the first from the genus Aphanius Nardo, 1827. Over 420 species of Gyrodactylus have been described $[19,20]$ and only six are known to parasitise cyprinodontids, all of them are recorded from Cyprinodon spp. (see Table 3). These are G. cyprinodontis, G. nevadensis and G. saratogensis, all from Cyprinodon nevadensis nevadensis Eigenmann et Eigenmann; G. hargisi and G. mobilensis from Cyprinodon variegatus variegatus Lacepède, and G. tularosae from Cyprinodon tularosa Miller et Echelle. No supporting molecular data, however, is available for any of these species. Morphologically, the marginal hook sickles of the Gyrodactylus species described from cyprinodontid hosts are markedly different (Figure 3). The marginal hook sickles of these species were re-drawn from the paratypes and holotypes, where available, and a comparison of their morphology with G. salinae n. sp. is given in Figure 3. The marginal hook sickles of G. cyprinodontis, G. nevadensis and G. saratogensis are morphologically very similar to one another (see Figure 3a, g, i). These three species were found on the 
Table 3 Gyrodactylus species parasitising different family members belonging to the order Cyprinodontiformes

\begin{tabular}{|c|c|c|c|}
\hline $\begin{array}{l}\text { Gyrodactylus } \\
\text { species }\end{array}$ & Recorded host species & Host family & References \\
\hline G. avalonia * & Fundulus diaphanus diaphanus (Lesueur) & Fundulidae & [40] \\
\hline G. bulbacanthus & Fundulus zebrinus (Jordan et Gilbert) & Fundulidae & [41] \\
\hline G. bullatarudis & $\begin{array}{l}\text { Poecilia mexicana Steindachner, Poecilia reticulata Peters, Poecilia sphenops Valenciennes, } \\
\text { Xiphophorus hellerii Heckel, X. hellerii } \times \text { Xiphophorus maculatus (Günther) hybrids }\end{array}$ & Poeciliidae & {$[25,42-44]$} \\
\hline G. costaricensis & P. sphenops & Poeciliidae & [45] \\
\hline G. cyprinodonti & Epiplatys fasciolatus (Günther) & Nothobranchiidae & [46] \\
\hline G. cyprinodontis & Cyprinodon nevadensis nevadensis Eigenmann et Eigenmann & Cyprinodontidae & [23] \\
\hline G. cytophagus & $\begin{array}{l}\text { Aplocheilichthys eduardensis (David et Poll), Aplocheilichthys normani Ahl, } \\
\text { Aplocheilichthys pumilus (Boulenger) }\end{array}$ & Poeciliidae & [46] \\
\hline G. funduli & Fundulus similis (Baird et Girard) & Fundulidae & {$[47]$} \\
\hline G. gambusiae & Gambusia affinis (Baird et Girard) & Poeciliidae & [48] \\
\hline G. hargisi & Cyprinodon variegatus variegatus Lacepède & Cyprinodontidae & [49] \\
\hline G. jarocho & X. hellerii & Poeciliidae & [25] \\
\hline G. lamothei & Girardinichthys multiradiatus (Meek) & Goodeidae & {$[50]$} \\
\hline G. mexicanus & G. multiradiatus & Goodeidae & [50] \\
\hline G. milleri & Poecilia caucana (Steindachner) & Poeciliidae & [51] \\
\hline G. mobilensis & Cyprinodon v. variegatus & Cyprinodontidae & [49] \\
\hline G. nevadensis & Cyprinodon n. nevadensis & Cyprinodontidae & [23] \\
\hline G. pictae & Micropoecilia picta Regan & Poeciliidae & [52] \\
\hline G. poeciliae & P. caucana & Poeciliidae & [51] \\
\hline G. rasini & X. hellerii & Poeciliidae & [53] \\
\hline G. recurvensis & Aplocheilus blockii (Arnold), Aplocheilus panchax (Hamilton) & Aplocheilidae & [54] \\
\hline G. salinae n. sp. & Aphanius fasciatus (Valenciennes) & Cyprinodontidae & $\begin{array}{l}\text { current } \\
\text { study }\end{array}$ \\
\hline G. saratogensis & Cyprinodon n. nevadensis & Cyprinodontidae & [23] \\
\hline G. stegurus & Fundulus d. diaphanus & Fundulidae & [55] \\
\hline G. stephanus & Fundulus grandis Baird et Girard, Fundulus heteroclitus heteroclitus (L.) & Fundulidae & {$[55,56]$} \\
\hline G. tularosae & Cyprinodon tularosa Miller et Echelle & Cyprinodontidae & [57] \\
\hline G. turnbulli & P. reticulata, Poeciliopsis sp. & Poeciliidae & {$[43,58]$} \\
\hline G. xalapensis & Heterandria bimaculata (Heckel) & Poeciliidae & [25] \\
\hline
\end{tabular}

* Gyrodactylus avalonia Hanek et Threlfall, 1969 is suspected to be a junior synonym of Gyrodactylus arcuatus Bychowsky, 1933, but until molecular characterisation of G. avalonia is available, this species is considered as valid (J. Lumme and S.D. King, pers. comm.).

same host, Cyprinodon n. nevadensis, and they differ in the size of their opisthaptor and its skeletal elements, notably the hamulus total length (G. cyprinodontis $=49$ $\mu \mathrm{m} ;$ G. nevadensis $=33 \mu \mathrm{m} ;$ G. saratogensis $=26 \mu \mathrm{m})$ which allows their ready discrimination from each other [23]. The opisthaptoral hooks of the type material of G. cyprinodontis and G. nevadensis were not completely flat and therefore reconstructed drawings of the marginal hook sickles of these two species were necessary and are presented here and compared with G. salinae n. sp. The marginal hook sickles of G. hargisi, G. mobilensis, G. tularosae and G. salinae n. sp. differ markedly in morphology from the other three species parasitising cyprinodontid hosts. When the gyrodactylid fauna on fish species belonging to the family Cyprinodontidae are considered and compared, then there are a number of species which possess similar marginal hook sickle morphologies. This has also been noted among species parasitising fish belonging to the pipefish family Syngnathidae, where the species Gyrodactylus eyipayipi Vaughan, Christison, Hansen et Shinn, 2010, Gyrodactylus neretum Paladini, Cable, Fioravanti, Faria et Shinn, 2010, Gyrodactylus pisculentus Williams, Kritsky, Dunnigan, Lash et Klein, 2008 and Gyrodactylus shorti Holliman, 1963, all possess a similar marginal hook sickle morphology [24]. The same is seen within species parasitising Poecilidae, whose gyrodactylids can be roughly allocated, based on their marginal hook sickle morphology, to one of three groups. The first group encompasses species with a large, approximately triangular sickle base and reduced sickle tips i.e. Gyrodactylus bullatarudis Turnbull, 1956, Gyrodactylus costaricensis Kritsky et Fritts, 1970, Gyrodactylus jarocho Rubio-Godoy, Paladini, García-Vásquez et Shinn, 2010 and Gyrodactylus poeciliae Harris et Cable, 2000. The second group of species which has large open faced sickles with a double 
angled sickle shaft and narrow sickle base i.e. Gyrodactylus gambusiae Rogers et Wellborn, 1965, Gyrodactylus milleri Harris et Cable, 2000 and Gyrodactylus turnbulli Harris, 1986. While the third group includes Gyrodactylus rasini Lucký, 1973 and Gyrodactylus xalapensis Rubio-Godoy, Paladini, García-Vásquez et Shinn, 2010 whose marginal hook sickles have rounded heels and approximately equal sized sickle shaft and point regions [25].

A list of all the species of Gyrodactylus recorded from cyprinodontids and other fish hosts belonging to the order Cyprinodontiformes is presented in Table 3. In addition to these, there are a number of other "Gyrodactylus" species parasitising cyprinodontiform hosts that appear in the literature. These include Gyrodactylus foxi Rawson, 1973, Gyrodactylus megacanthus Wellborn et Rogers, 1967, Gyrodactylus prolongis Hargis, 1955, Gyrodactylus stableri Hathaway et Herlevich, 1973 and Gyrodactylus trematoclithrus Rogers, 1967, all of which were subsequently transferred to the genus Fundulotrema Kritsky et Thatcher, 1977 based on the presence of an additional peduncular bar [26].

The fact that the current species is (both morphologically and molecularly) more closely related to Gyrodactylus species parasitising marine gobies and eels than to those infecting cyprinodontids, might suggest that the ecology of the host, rather than host phylogeny plays an important role in this host-parasite system. Malmberg [10] found G. anguillae only on migrating elvers, which are relatively small and abundantly found in estuaries, as is the common goby Pomatoschistus microps (Krøyer), host to G. micropsi. There are other examples of ecological radiations onto distant-related hosts in Gyrodactylus, e.g. the G. wageneri-group primarily infects cyprinids but they are also found on sticklebacks, percids and cottids [27].

There is nothing known yet on the effect of G. salinae n. sp. on its host, but its closest relative so far, G. anguillae, has been reported as a pest in the culture of anguillid eels $[28,29]$.

Based on the nuclear ITS fragment, the genus Gyrodactylus can be divided in two groups, one with a 'short' (347-473 bp) and one with a 'long' (535-688 bp) ITS1 fragment $[30,31]$. These ranges have recently been extended both to the lower end, with Gyrodactylus cichlidarum Paperna, 1968 having the shortest ITS1 sequence determined thus far (343 bp; acc. no. DQ124228), and G. salinae n. sp. having the longest ITS1 fragment (774 bp). The sequence of G. salinae n. sp. is also unique as the $5.8 \mathrm{~S}$ gene is $158 \mathrm{bp}$ long, whereas all other Gyrodactylus species so far had an invariant length of $157 \mathrm{bp}$. The new species clusters in the marine rugiensis-group which is part of the monophyletic 'long ITS' group, and appears most closely related to G. anguillae. Despite the morphological resemblance between G. salinae n. sp. and G. rugiensoides, they are genetically quite different (especially in the ITS1 fragment). This underlines again the fact that morphological and molecular evolution is not always correlated. The close affinity with $G$. anguillae and Gyrodactylus cf. micropsi Huyse, Audenaert et Volckaert, 2003 as based on the genetic distances does not necessarily equal sister species relationships. The true sister species of G. salinae n. sp. has probably not been sequenced yet since the difference between Gyrodactylus species from closely related goby species was for example much smaller (2-5\%) [32] than the distance between G. anguillae and G. salinae n. sp.

\section{Conclusions}

Although the specimens of $A$. fasciatus from Cervia Saline were moribund at the time of collection, this was not a consequence of the moderate G. salinae n. sp. infection but of the pool conditions $\left(30^{\circ} \mathrm{C}, 65 \mathrm{ppt}\right)$ from which they were collected which had a water depth of less than $15 \mathrm{~cm}$ and a heavy growth of algae. Given the ability of G. salinae n. sp. to tolerate a wide range of salinities and temperatures, it would appear that this species has the potential to readily adapt to the full spectrum of environmental conditions. What is unknown, however, is the potential of this species to survive on other neritic fish hosts when cohabiting isolated pools or interacting with other fish species in open, full strength seawater (i.e. $35 \mathrm{ppt}$ ). The potential utility of Aphanius fasciatus as a biological control against the larvae of the Asian tiger mosquito Stegomyia albopicta, in addition to the finding of a new parasite species, raises concerns regarding the health status of this host due to the parasitic infection. Further studies are required in order to define the potential role of $G$. salinae $\mathrm{n}$. sp. as a pathogen, and the consequences that this finding might have on the use of indigenous populations of $A$. fasciatus as an alternative biological control to the use of various Gambusia species. The ecological risks of introducing Gambusia spp. to non-native environments has been stressed by many authors [33-35]. Cross breeding with indigenous species may lead to the extinction of the latter given that certain species have been shown to hybridise [36-38]. There are also the attendant risks of disease introduction linked with the movement of fish into new habitats [39]. The use of native fish, rather than introduced species, as biological controls, therefore, is highly recommended to avoid these potential ecological impacts.

In accordance with section 8.6 of the ICZN's International Code of Zoological Nomenclature, copies of this article are deposited at the following five publicly accessible libraries: Natural History Museum, London, UK; 
American Museum of Natural History, New York, USA; Museum National d'Histoire Naturelle, Paris, France; Russian Academy of Sciences, Moscow, Russia; Academia Sinica, Taipei, Taiwan.

\section{Acknowledgements}

The authors would like to thank Mr Antonio Casalini, Mr Giuseppe Bastone and Dr Oliviero Mordenti (Faculty of Veterinary Medicine, University of Bologna, Italy) for providing literature and moribund fish for study; Mr Linton Brown (Institute of Aquaculture, University of Stirling, UK) for technical assistance with the acquisition of scanning electron photomicrographs; Mrs Eileen Harris (The Natural History Museum, London, UK) and Mrs Patricia Pilitt (United States National Parasite Collection, Beltsville, Maryland, USA) for the loan of type material from international collections. This study was conducted during the tenure of a PhD scholarship from the Department of the Environment, Food and Rural Affairs (Defra), UK (project no. FC1183) awarded to APS and conducted by GP. TH is currently a Postdoctoral Fellow of the Research Foundation - Flanders (FWO-Vlaanderen).

\section{Author details}

'Institute of Aquaculture, University of Stirling, Stirling, FK9 4LA, Scotland, UK. ${ }^{2}$ Katholieke Universiteit Leuven, Laboratory of Animal Diversity and Systematics, Ch. Deberiotstraat 32, B-3000 Leuven, Belgium.

\section{Authors' contributions}

GP and APS conducted the morphological and morphometrical analyses, TH performed the molecular analysis. GP, APS and TH co-drafted the manuscript together. All authors read and approved the final version of the manuscript.

\section{Competing interests}

The authors declare that they have no competing interests.

Received: 31 March 2011 Accepted: 9 June 2011 Published: 9 June 2011

\section{References}

1. Froese R, Pauly D: FishBase, World Wide Web electronic publication. 2010 [http://www.fishbase.org], last access 12/2010.

2. Triantafyllidis A, Leonardos I, Bista I, Kyriazis ID, Stoumboudi MT, Kappas I, Amat F, Abatzopoulos TJ: Phylogeography and genetic structure of the Mediterranean killifish Aphanius fasciatus (Cyprinodontidae). Mar Biol 2007, 152:1159-1167.

3. Mordenti O, Trentini M, Bastone G, Savoia L, Scaravelli D: Caratterizzazioni ecologiche e morfologiche di Aphanius fasciatus (Valencienne, 1821). Biol Mar Medit 2008, 15(1):306-307 [In Italian with English summary].

4. Crivelli AJ: Aphanius fasciatus. IUCN 2010 IUCN Red List of Threatened Species 2006 [http://http//www.iucnredlist.org], Version 2010.4 (last access 03/2011).

5. Miller BR, Ballinger ME: Aedes albopictus mosquitoes introduced into Brazil: vector competence for yellow fever and dengue viruses. Trans $R$ Soc Trop Med Hyg 1988, 82(3):476-477.

6. Sardelis MR, Turell MJ, O'Guinn ML, Andre RG, Roberts DR: Vector competence of three North American strains of Aedes albopictus for West Nile virus. J Am Mosa Control Assoc 2002, 18(4):284-289.

7. Cinti S: Chikungunya fever: an emerging infection. Infect Dis Clin Pract 2009, 17(1):6-11.

8. Mordenti O, Scaravelli D, Trentini M, Zaccaroni A, Gamberoni M: Reproduction of Aphanius fasciatus induced by ecophysiological conditioning and hormonal treatment. Biol Mar Medit 2007, 14(2):276-277 [In Italian with English summary].

9. Mordenti O, Scaravelli D, Trentini M: Prove di controllo su Aedes albopictus (Skuse, 1894): sperimentazione di alimentazione su larve da parte di Aphanius fasciatus (Valencienne, 1821) (Cyprinodontiformes, Cyprinodontidae). Proc XXII Congr Naz Ital Entomol, 15th-18th June 2009, Ancona (Italy): 267 [In Italian].

10. Malmberg G: The excretory systems and the marginal hooks as a basis for the systematics of Gyrodactylus (Trematoda, Monogenea). Ark Zool 1970, 23:1-235.

11. Paladini G, Gustinelli A, Fioravanti ML, Hansen H, Shinn AP: The first report of Gyrodactylus salaris Malmberg, 1957 (Platyhelminthes, Monogenea) on Italian cultured stocks of rainbow trout (Oncorhynchus mykiss Walbaum). Vet Parasitol 2009, 165:290-297.

12. Shinn AP, Hansen H, Olstad K, Bachmann L, Bakke TA: The use of morphometric characters to discriminate species of laboratory-reared and wild populations of Gyrodactylus salaris and G. thymalli (Monogenea). Folia Parasitol 2004, 51:239-252.

13. Matějusová I, Gelnar M, McBeath AJA, Collins CM, Cunningham CO: Molecular markers for gyrodactylids (Gyrodactylidae: Monogenea) from five fish families (Teleostei). Int J Parasitol 2001, 31:738-745.

14. Ziętara MS, Lumme J: Speciation by host switch and adaptive radiation in a fish parasite genus Gyrodactylus (Monogenea, Gyrodactylidae). Evolution 2002, 56:2445-2458.

15. Altschul SF, Gish W, Miller W, Myers EW, Lipman DJ: Basic local alignment search tool. J Mol Biol 1990, 215:403-410.

16. Tamura K, Dudley J, Nei M, Kumar S: MEGA4: Molecular Evolutionary Genetics Analysis (MEGA) software version 4.0. Mol Biol Evol 2007, 24:1596-1599.

17. Posada D: jModelTest: phylogenetic model averaging. Mol Biol Evol 2008, 25:1253-1256.

18. Benson G: Tandem repeats finder: a program to analyze DNA sequences. Nucl Acids Res 1999, 27:573-580.

19. Shinn AP, Harris PD, Cable J, Bakke TA, Paladini G, Bron JE: GyroDb. World Wide Web electronic publication. 2011 [http://www.gyrodb.net], last access 03/2011.

20. Shinn AP, Paladini G, Rubio-Godoy M, Domingues MV, Whittington ID, Bron JE: MonoDb. A web-host for Monogenea. World Wide Web electronic publication. 2011 [http://www.monodb.org], last access 03/2011.

21. Tamura K, Nei M: Estimation of the number of nucleotide substitutions in the control region of mitochondrial DNA in humans and chimpanzees. Mol Biol Evol 1993, 10:512-526.

22. Huyse T, Volckaert FAM: Identification of a host-associated species complex using molecular and morphometric analyses, with the description of Gyrodactylus rugiensoides n. sp. (Gyrodactylidae, Monogenea). Int J Parasitol 2002, 32:907-919.

23. Mizelle JD, Kritsky DC: Studies on monogenetic trematodes. XXXVI. Gyrodactylid parasites of importance to California fishes. Calif Fish Game 1967, 53:264-272.

24. Paladini G, Cable J, Fioravanti ML, Faria PJ, Shinn AP: The description of Gyrodactylus corleonis sp. n. and G. neretum sp. n. (Platyhelminthes: Monogenea) with comments on other gyrodactylids parasitising pipefish (Pisces: Syngnathidae). Folia Parasitol 2010, 57(1):17-30.

25. Rubio-Godoy M, Paladini G, García-Vásquez A, Shinn AP: Gyrodactylus jarocho sp. nov. and Gyrodactylus xalapensis sp. nov. (Platyhelminthes: Monogenea) from Mexican poeciliids (Teleostei: Cyprinodontiformes), with comments on the known gyrodactylid fauna infecting poeciliid fish. Zootaxa 2010, 2509:1-29.

26. Kritsky DC, Thatcher VE: Phanerothecium gen. nov. and Fundulotrema gen. nov. two new genera of viviparous Monogenoidea (Gyrodactylidae), with a description of $P$. caballeroi sp. nov, and a key to the subfamilies and genera of the family. Excerta Parasitol Mem Dr Eduardo Caballero y Caballero Inst Biol Publ Esp 1977, 4:53-60.

27. Harris PD: Interactions between reproduction and population biology in gyrodactylid monogeneans - a review. Bull Fr Pêche Piscic 1993, 328:47-65.

28. Hayward CJ, Iwashita M, Crane JS, Ogawa K: First report of the invasive eel pest Pseudodactylogyrus bini in North America and in wild American eels. Dis Aquat Org 2001, 44:53-60.

29. Grano-Maldonado MI, Gisbert E, Hirt-Chabbert J, Paladini G, Roque A, Bron JE, Shinn AP: An infection of Gyrodactylus anguillae Ergens, 1960 (Monogenea) associated with the mortality of glass eels (Anguilla anguilla L.) on the north-western Mediterranean Sea board of Spain. Vet Parasitol 2011.

30. Cable J, Harris PD, Tinsley RC, Lazarus CM: Phylogenetic analysis of Gyrodactylus spp. (Platyhelminthes: Monogenea) using ribosomal DNA sequences. Can J Zool 1999, 77:1439-1449.

31. Ziętara MS, Huyse T, Lumme J, Volckaert FAM: Deep divergence among subgenera of Gyrodactylus inferred from rDNA ITS region. Parasitology 2002, 124:39-52.

32. Huyse T, Malmberg G, Volckaert FAM: Four new species of Gyrodactylus von Nordmann, 1832 (Monogenea, Gyrodactylidae) on gobiid fishes: combined DNA and morphological analyses. Sys Parasitol 2004, 59:103-120. 
33. Leyse KE, Lawler SP, Strange T: Effects of an alien fish, Gambusia affinis, on an endemic California fairy shrimp, Linderiella occidentalis: implications for conservation of diversity in fishless waters. Biol Conserv 2004, 118:57-65.

34. García-Berthou E, Alcaraz C, Pou-Rovira Q, Zamora L, Coenders G, Feo C: Introduction pathways and establishment rates of invasive aquatic species in Europe. Can J Fish Aquat Sci 2005, 62:453-463.

35. Reichard M, Watters BR, Wildekamp RH, Sonnenberg R, Nagy B, Polačik M, Valdesalici S, Cellerino A, Cooper BJ, Hengstler H, Rosenstock J, Sainthouse I: Potential negative impacts and low effectiveness in the use of African annual killifish in the biocontrol of aquatic mosquito larvae in temporary water bodies. Parasit Vectors 2010, 3:89.

36. Ryan MJ, Wagner WE Jr: Asymmetries in mating preferences between species: female swordtails prefer heterospecific males. Science 1987, 236:595-597.

37. Rosenfield J, Kodric-Brown A: Sexual selection promotes hybridization between Pecos pupfish, Cyprinodon pecosensis-C. variegatus and sheepshead minnow. J Evol Biol 2003, 16:595-606.

38. Wong BBM, Fisher HS, Rosenthal GG: Species recognition by male swordtails via chemical cues. Behav Ecol 2005, 16:818-822.

39. Daszak P, Cunningham AA, Hyatt AD: Emerging infectious diseases of wildlife - threats to biodiversity and human health. Science 2000, 287:443-449.

40. Dechtiar A, Christie WJ: Survey of the parasite fauna of Lake Ontario fishes, 1961-1971. In Parasites of Fishes in the Canadian Waters of the Great Lakes Great Lakes Fishery Commission Technical Report no 51. Edited by: Nepszy SJ. Ann Arbor, Michigan; 1988:66-95.

41. Mayes MA: New species of Gyrodactylus and Dactylogyrus (Trematoda: Monogenea) from fishes of Nebraska. J Parasitol 1977, 63:805-809.

42. Turnbull ER: Gyrodactylus bullatarudis n. sp. from Lebistes reticulatus Peters with a study of its life-cycle. Can J Zool 1956, 34:583-594.

43. Harris PD: Species of Gyrodactylus von Nordmann, 1832 (Monogenea: Gyrodactylidae) from poeciliid fishes, with a description of G. turnbulli sp. nov. from the guppy, Poecilia reticulata Peters. J Nat Hist 1986, 20:183-191.

44. Dove ADM, Ernst I: Concurrent invaders - four exotic species of Monogenea now established on exotic freshwater fishes in Australia. Int J Parasitol 1998, 28:1755-1764.

45. Kritsky DC, Fritts TH: Monogenetic trematodes from Costa Rica with the proposal of Anacanthocotyle gen. n. (Gyrodactylidae: Isancistrinae). Proc Helminthol Soc Wash 1970, 37:63-68.

46. Paperna I: Monogenetic trematodes collected from freshwater fishes in Ghana. Second report. Bamidgeh 1968, 20:88-90.

47. Hargis WJ: Monogenetic trematodes of Gulf of Mexico fishes. Part I. The superfamily Gyrodactyloidea. Biol Bull 1955, 108:125-137.

48. Rogers WA, Wellborn TL Jr: Studies on Gyrodactylus (Trematoda: Monogenea) with descriptions of five new species from the southeastern U.S. J Parasitol 1965, 51:977-982.

49. Williams EH Jr, Rogers WA: Two new species of Gyrodactylus (Trematoda: Monogenea) and a redescription and new host record for $G$. prolongis Hargis, 1955. J Parasitol 1971, 57:845-847.

50. Mendoza-Palmero CA, Sereno-Uribe AL, Salgado-Maldonado G: Two new species of Gyrodactylus von Nordmann, 1832 (Monogenea: Gyrodactylidae) parasitizing Girardinichthys multiradiatus (Cyprinodontiformes: Goodeidae), an endemic freshwater fish from central Mexico. J Parasitol 2009, 95:315-318.

51. Harris PD, Cable J: Gyrodactylus poeciliae n. sp. and G. milleri n. sp. (Monogenea: Gyrodactylidae) from Poecilia caucana (Steindachner) in Venezuela. Sys Parasitol 2000, 47:79-85.

52. Cable J, van Oosterhout C, Barson N, Harris PD: Gyrodactylus pictae n. sp. (Monogenea: Gyrodactylidae) from the Trinidadian swamp guppy Poecilia picta Regan, with a discussion on species of Gyrodactylus von Nordmann, 1832 and their poeciliid hosts. Sys Parasitol 2005, 60:159-164

53. Lucký Z: Gyrodactylus rasini n. sp. (Monogenoidea: Gyrodactylidae) a parasite on the gills of Xiphophorus hellerii bred as an aquarium fish in Czechoslovakia. Vet Med 1973, 18:647-652.

54. Rukmini C, Madhavi R: Gyrodactylus recurvensis n. sp. (Monogenea, Gyrodactylidae) from larvivorous fishes Aplocheilus panchax and $A$. blocki. Indian J Helminthol 1989, 6:17-20.

55. Mueller JF: Further studies on North American Gyrodactyloidea. Am Midl Nat 1937, 18:207-219.
56. King SD, Cone DK: Morphological and molecular taxonomy of a new species of fundulotrema and comments on Gyrodactylus stephanus (Monogenea: Gyrodactylidae) from Fundulus heteroclitus (Actinopterygii: Cyprinodontiformes) in Nova Scotia, Canada. J Parasitol 2009, 95(4):846-849.

57. Kritsky DC, Stockwell CA: New species of Gyrodactylus (Monogenoidea, Gyrodactylidae) from the white sands pupfish, Cyprinodon tularosa, in New Mexico. Southwest Nat 2005, 50(3):312-317.

58. An L, Jara CA, Cone DK: Five species of Gyrodactylus Nordmann, 1832 (Monogenea) from fresh-water fishes of Peru. Can J Zool 1991, 69:1199-1202.

doi:10.1186/1756-3305-4-100

Cite this article as: Paladini et al:: Gyrodactylus salinae n. sp.

(Platyhelminthes: Monogenea) infecting the south European toothcarp Aphanius fasciatus (Valenciennes) (Teleostei, Cyprinodontidae) from a hypersaline environment in Italy. Parasites \& Vectors 2011 4:100.

\section{Submit your next manuscript to BioMed Central and take full advantage of:}

- Convenient online submission

- Thorough peer review

- No space constraints or color figure charges

- Immediate publication on acceptance

- Inclusion in PubMed, CAS, Scopus and Google Scholar

- Research which is freely available for redistribution

Submit your manuscript at www.biomedcentral.com/submit
Ciomed Central 